\title{
PEMETAAN POTENSI UMKM DI DESA PANENJOAN, KABUPATEN BANDUNG, JAWA BARAT
}

\author{
Raden Marsha Aulia Hakim \\ Departemen Administrasi Bisnis, Universitas Padjadjaran \\ E-Mail: marsha.aulia@unpad.ac.id
}

\begin{abstract}
ABSTRAK. Pemetaan potensi UMKM di Desa Panenjoan, Kabupaten Bandung dilakukan untuk mengetahui potensi yang dimiliki UMKM di Desa dan diharapkan akan memunculkan produk unggulan bagi Desa. Tujuan dari penelitian ini adalah melihat bagaimana potensi yang dimiliki UMKM Desa Panenjoan berdasarkan dari fungsi bisnisnya. Metode penelitian ini dilakukan dengan analisis deskriptif kualitatif dan melalui wawancara mendalam dengan para pelaku usaha yang berada di Desa Panenjoan. Berdasarkan dari hasil pemetaan, diketahui bahwa UMKM di Desa Panenjoan memiliki potensi cukup besar karena banyaknya usaha yang telah memasarkan produknya sampai wilayah Jawa Barat, namun untuk mendukung penjualan produknya ini diperlukan legalitas usaha yang akan mendukung perluasan pasar bagi usaha-usaha tersebut.
\end{abstract}

Kata kunci: Pemetaan potensi; UMKM; Fungsi bisnis

ABSTRACT. Potential mapping of MSMEs in Panenjoan Village, Bandung District is conducted to find out potential MSMEs in the village and is expected to bring up excellence products for the village. The purpose of this study is to see how the potential of the Panenjoan Village UMKM is based on its business function. This research method was conducted with a descriptive qualitative analysis and through in-depth interviews with business people in the Panenjoan Village. Based on the results of the mapping, it is known that MSMEs in Panenjoan Village have considerable potential because many businesses have marketed their products to the West Java region, but to support the sale of these products a business legality is needed that will support the expansion of the market for these businesses.

Keywords: Potential mapping; MSMEs; Business Function

\section{PENDAHULUAN}

UMKM di Indonesia sejak tahun 1998 menjadi awal sadarnya pemerintah bahwa hanya sektor inilah yang mampu bertahan ketika terjadi krisis ekonomi. Pengalaman yang terjadi pada saat itu, membuat Indonesia mempertahankan dan mendorong pengembangan UMKM di setiap daerah. Suci (2017) menjelaskan bahwa terdapat potensi yang dapat dikembangkan pada UMKM, terlihat dari penyerapan tenaga kerja dan sumbangannya terhadap PDB, yaitu $99,45 \%$ merupakan penyerapan tenaga kerja dan 30\% merupakan sumbangannya terhadap PDB. Tingginya penyerapan maupun adanya kontribusi yang cukup baik terhadap PDB, dapat dikatakan UMKM memberikan sumbangan perekonomian yang penting bagi Indonesia. Hal ini, membuat setiap pemimpin daerah perlu mewujudkan pengembangan UMKM di daerahnya untuk mencapai target ekonomi yang semakin baik. Salah satunya adalah Jawa Barat yang telah memperhatikan UMKM di wilayahnya.

Jawa Barat sudah beberapa tahun belakang sangat memperhatikan UMKM, sehingga terwujud salah satu programnya, yaitu "UMKM Juara". Program ini memberikan dorongan kuat bagi setiap daerah untuk meningkatkan potensi UMKMnya. Bahkan bagi setiap desa di daerah Jawa Barat, harus memiliki produk unggulan yang bisa menjadi citra bagi desa tersebut. Hal ini diharapkan dapat membangun ekonomi di daerah pedesaan, dimana masyarakat di desa dapat lebih sejahterah. Produk unggulan bisa menjadi salah satu cara untuk memperkenalkan desa ke berbagai daerah lainnya.

Desa Panenjoan merupakan salah satu dari 12 desa dari Kecamatan Cicalengka, Kabupaten Bandung dengan luas desa sebesar $161.000 \mathrm{Ha}$. Desa Panenjoan memiliki 3 dusun dengan 11 RW dan 53 RT. Berdasarkan dari data demografi di desa, sebagian besar warganya bekerja sebagai PNS sebesar 27.56\% dari total penduduk Desa Panenjoan. Selain itu terdapat sebesar $1.43 \%$ warga desa panenjoan yang bekerja sebagai pedagang atau memiliki usaha. Namun terdapat $18 \%$ warga desa Panenjoan tidak memiliki pekerjaan. Salah satu cara untuk mengatasi pengurangan jumlah pengangguran dengan meningkatkan ekonomi warga untuk memiliki usahanya sendiri.

Apabila dilihat dari potensi wilayahnya, desa panenjoan terletak di dekat jalan bypass Rancaekek dimana terdapat industri-industri besar di sekelilingnya. Potensi untuk memiliki usaha di sekitar wilayah ini, bisa menjadi potensi pasar yang cukup bersaing dimana terdapat pekerja di industri tersebut dengan jumlah yang tinggi. Keberlangsungan usaha yang sudah dimiliki warga perlu dikembangkan lagi sehingga bisa menarik warga sekitarnya untuk bekerja di usaha tersebut. Berdasarkan dari wawancara pertama, diketahui bahwa Desa Panenjoan belum memiliki produk unggulan Desa, sehingga dalam kegiatan ini akan 
berfokus pada pemetaan UMKM di Desa Panenjoan untuk mendapatkan produk unggulan.

Selain itu, Lembaga Masyarakat yang memiliki pengaruh terhadap pengembangan UMKM di Desa adalah BUMDES, kemudian dibantu dengan Lembaga lainnya seperti PKK, kader-kader, dan MUI. Beberapa Lembaga tersebut sudah melakukan tugasnya untuk mengembangkan potensi wirausaha maupun pengelolaan usaha. BUMDES sendiri di desa ini baru terbentuk dan dalam pengelolaannya belum sempurna sehingga persebarannya untuk membangun UMKM setempat masih belum terlaksanakan dengan baik. Sejauh ini, selalu ada dana yang digulirkan dari pemerintah pusat ke desa dan diharapkan dana tersebut dapat terus bergulir sehingga bermanfaat secara berkelanjutan. Pemetaan potensi dapat membantu pemerintah maupun Lembaga untuk mendapatkan informasi yang tepat mengenai kebutuhan UMKM di Desa Panenjoan. Desa Panenjoan sendiri memiliki banyak pengusaha yang bergerak di berbagai bidang seperti produksi kerudung, jajanan tradisional dan lainnya.

Berdasarkan Undang-Undang Nomor 20 Tahun 2008 tentang Usaha Mikro, Kecil dan Menengah (UMKM), usaha mikro adalah usaha produktif milik orang perorangan dan/atau badan usaha perorangan yang memenuhi kriteria Usaha Mikro. Menurut Kementrian Menteri Negara dan Koperasi dan Usaha Kecil Menengah (Menegkop dan UKM), bahwa yang dimaksud dengan Usaha Kecil (UK), termasuk Usaha Mikro (UMI), adalah entitas usaha yang mempunyai memiliki kekayaan bersih paling banyak Rp 200.0000.000, tidak termasuk tanah dan bangunan tempat usaha, dan memiliki penjualan tahunan paling banyak Rp. 1.000.000.000. Sementara itu, Usaha Menengah (UM) merupakan entitas usaha milik warga negara Indonesia yang memiliki kekayaan bersih lebih besar dari Rp 200.000 .000 s.d. Rp 10.000.000.000, tidak termasuk tanah dan bangunan. Berdasarkan hal tersebut, hanya usaha mikro yang akan menjadi fokus peneliti untuk memberikan wawasan lebih dan menggambarkan potensi usaha mikro yang ada di Desa Panenjoan.

Penggambaran potensi UMKM dapat dilihat melalui 4 fungsi bisnis, yaitu operasi, sumber daya manusia, pemasaran dan keuangan. 4 fungsi bisnis merupakan aspek-aspek yang perlu diperhatikan dalam sebuah rangkaian proses bisnis di dalam suatu usaha (Ebert \& Griffin, 2019). Sumber Daya Manusia (SDM) merupakan aspek dimana suatu usaha memiliki tanggung jawab terhadap seluruh aktivitas sumber dayanya. Operasi merupakan salah satu proses yang akan bertanggung jawab dalam bagian produksi, penyimpanan dan pengendalian kualitas. Pemasaran akan membicarakan mengenai bagaimana sebuah produk yang diciptakan perusahaan dapat dikenal konsumen, hal ini dapat dilihat mulai dari pendistribusian produknya, promosi, harga. Keuangan merupakan aspek yang melihat perencanaan keuangan dan berbagai fungsi akuntansi serta sumber daya keuangan yang bisa dikembangkan oleh perusahaan. Setidaknya dalam melihat sebuah usaha yang telah melakukan suatu proses bisnis akan menjalani keempat fungsi bisnis ini.

Pemetaan potensi UMKM di Desa Panenjoan ini dilakukan dengan melihat terlebih dahulu potensi usaha melalui profil dari setiap usaha pada aspek empat fungsi bisnis tersebut. Apabila dilihat dari keempat aspek akan terlihat keunggulan yang diciptakan oleh setiap usaha untuk memenangkan persaingan. Utamanya dengan pemetaan potensi, bisa memberikan gambaran kepada pemerintah Desa dalam melihat produk yang bisa dijadikan sebagai produk unggulannya. Selama ini Desa Panenjoan, belum memiliki produk unggulan sehingga untuk mendukung program pemerintah pusat dalam mensejahterahkan dan mengenalkan Desa maka pemilihan produk unggulan akan menjadi penting. Salah satunya melalui pemetaan potensi usaha terlebih dahulu untuk mengetahui secara mendalam kegiatan usaha yang dimiliki di Desa Panenjoan.

\section{METODE}

Metode penelitian yang digunakan dalam penelitian ini adalah metode penelitian kualitatif. Metode kualitatif berdasarkan pendapat Sugiyono (2010) adalah metode yang digunakan penelitian dengan berlandaskan filsafat positivisme, digunakan untuk meneliti pada kondisi objek sesuai aslinya, dengan peneliti sebagai key instrument. Metode penelitian yang digunakan oleh peneliti dengan metode analisis deskriptif dengan pendekatan kualitatif. Hal ini akan memberikan analisis data yang deskriptif sehingga akan memberikan gambaran dari pernyataan responden. Penelitian secara deskriptif akan memberikan gambaran yang lebih kompleks terhadap suatu tatanan masyarakat (Mantra, 2004). Metode deskriptif akan memberikan penelitian terhadap variabel secara mandiri tanpa membuat sebuah perbandingan atau hubungan antar variabel (Sugiyono, 2010). Pengumpulan data pada penelitian ini melalui sumber data sekunder dan primer. Sumber data sekunder melalui berbagai literasi ilmiah, buku, artikel, dan internet. Sumber primer berasal dari pelaku usaha UMKM yang berada di Desa Panenjoan. Pihak yang akan diwawancarai terdiri dari 9 UMKM dan juga terdiri dari pemilik usaha tersebut. UMKM tersebut terdiri dari beberapa jenis usaha, yaitu usaha konstruksi, hewan peliharaan dan kuliner. Pengumpulan data primer ini dilakukan dengan cara wawancara secara 
langsung dengan pemilik usaha sehingga peneliti dapat mengetahui secara langsung kenyataan yang ada di lapangan. Jenis wawancara ini sudah termasuk dalam kategori in-depth interview, dimana dalam pelaksanaannya lebih bebas dibandingkan dengan wawancara terstruktur. Tujuan dari wawancara jenis ini adalah untuk menemukan permasalahan secara lebih terbuka, dimana pihak yang diajak wawancara diminta pendapat, dan ide-idenya. Keseluruhan wawancara akan dianalisa secara terstruktur dengan melakukan pengklasifikasian pada beberapa kategori untuk mempermudah dalam melihat profil potensi usahanya.

\section{HASIL DAN PEMBAHASAN}

Pada bagian ini peneliti akan membahas hasil wawancara mendalam pada pemilik usaha UMKM di Desa Panenjoan dengan tujuan dapat "pemetaan potensi UMKM Desa Panenjoan". UMKM telah menjadi perhatian dari berbagai stakeholder dalam upaya menguatkan perekonomian di suatu daerah. Terutama di wilayah Desa, aspek UMKM tidak luput menjadi perhatian untuk menambahkan kontribusi perekonomian, seperti dibentuknya BUMDES dsb. Terkait hal tersebut, diperlukan pemetaan potensi UMKM di Desa Panenjoan sehingga dapat memberikan masukan untuk pengembangan potensi UMKM. Berikut akan dijelaskan terlebih dahulu mengenai profil usaha yang diteliti, yaitu:

1. Konstruksi (2 Usaha)

2. Hewan Peliharaan (1 Usaha)

3. Kuliner (6 Usaha)

Total keseluruhan, terdapat 9 usaha yang dilakukan pemetaannya oleh peneliti yang melihat dari sisi kriteria bahwa usaha ini masih termasuk dalam UMKM, seperti penjelasan berikut:

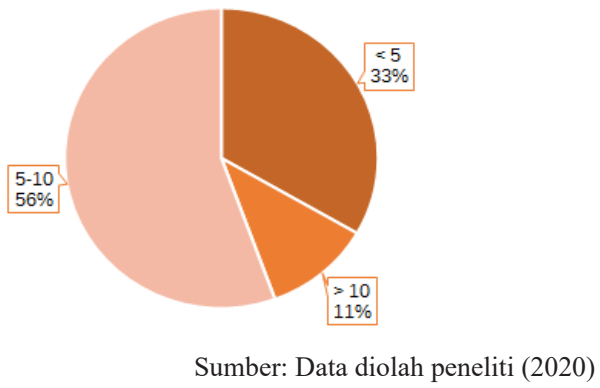

Gambar 1. Jumlah SDM UMKM Desa Panenjoan

Berdasarkan dari gambar 1, dapat terlihat bahwa 33\% dari UMKM tersebut masih industri rumahan, sedangkan bagi usaha yang memiliki Sumber Daya Manusia (SDM) lebih dari 5 termasuk dalam usaha mikro. Hal ini terlihat bahwa masih banyak usaha yang masih dalam skala mikro, dimana jumlah capaian pasarnya masih cukup rendah sehingga tidak akan memerlukan tenaga kerja yang banyak. UMKM yang ditinjau secara langsung di lapangan, merupakan usaha yang melakukan produksi secara mandiri dimana mulai dari mendapatkan pasokan hingga pendistribusian produknya dilakukan oleh pelaku usaha. Selain itu perlu dilihat juga berdasarkan legalitas usaha yang ada dari UMKM ini. Apabila suatu usaha semakin maju akan ditandai dengan legalitas usaha yang telah dimiliki.

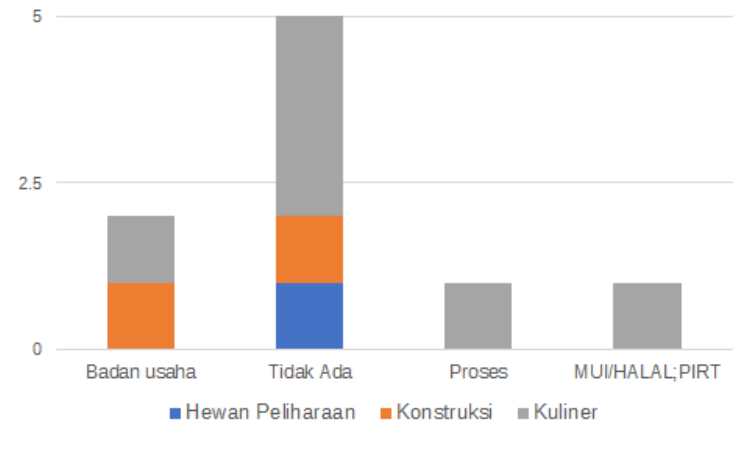

Sumber: Data diolah peneliti (2020)

\section{Gambar 2. Legalitas Usaha UMKM Desa Panenjoan}

Terdapat 5 usaha yang belum memiliki legalitas usaha, sedangkan usaha lainnya telah memulai untuk memiliki legalitas. Hal ini terlihat bahwa beberapa pelaku usaha telah menyadari pentingnya legalitas usaha untuk kemajuan usahanya. Apabila pelaku usaha memiliki legalitas akan terlihat keseriusan untuk membuat usahanya semakin berkelanjutan, utamanya dengan memiliki badan usaha. Badan usaha akan memberikan kewenangan bagi usaha untuk mendapatkan peluang lebih besar dalam memasarkan usahanya dan menjadikan salah satu komponen untuk meningkatkan kepercayaan bagi mitra kerjanya. Selain itu, terdapat juga usaha yang telah memiliki label halal dan PIRT. Hal ini menunjukkan bahwa usaha tersebut sudah memiliki kesadaran pentingnya komponen yang digunakan untuk memproduksi produknya bagi konsumsi konsumen. Tidak hanya dari segi pelaku usaha, ini juga meningkatkan kepercayaan konsumen terhadap produk yang dipasarkannya.

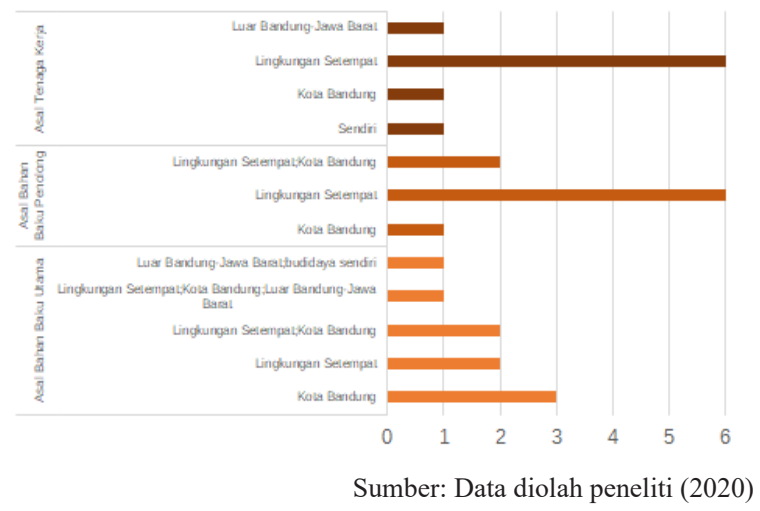

Gambar 3. Sumber Daya Produksi UMKM Desa Panenjoan 
Secara keseluruhan, asal dari sumber daya yang dimiliki dari lingkungan setempat. Hal ini menunjukkan bahwa pelaku usaha di Desa Panenjoan tidak sulit untuk mendapatkan bahan baku utama, penolong maupun tenaga kerja. Adanya integrasi yang baik untuk mendapatkan bahan baku seperti ini akan membantu keberlangsungan usaha dimana tidak sulitnya untuk mencapai bahan bakunya. Kemudian, pelaku usaha juga secara tidak langsung bersamasama membangun perekonomian daerah dengan melakukan pembelian bahan baku di daerahnya sendiri. Selain itu, mengurangi tingkat pengangguran di Desa Panenjoan dengan mempekerjakan tenaga kerja yang berasal dari Desa Panenjoan.

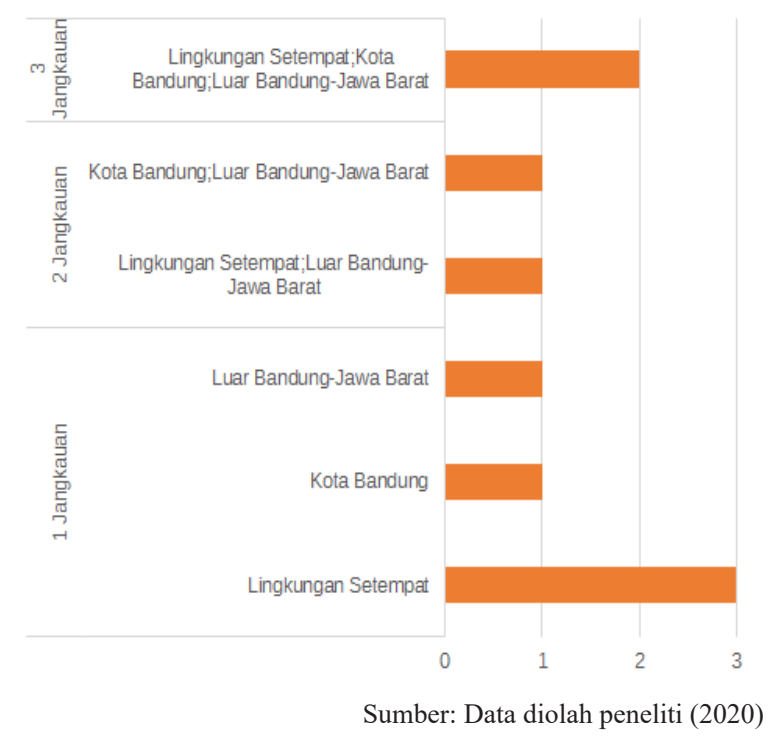

Gambar 4. Luas Jangkauan Penjualan UMKM Desa Panenjoan

Pelaku usaha secara umum masih memasarkan produk di lingkungan setempat. Walaupun berdasarkan dari data sebelumnya, pelaku usaha telah memiliki legalitas usaha yang dapat mendukung usahanya namun hal tersebut tidak membuat perluasan dalam melakukan penjualan produknya. Hanya terdapat 5 usaha yang telah berani memasarkan produknya sampai daerah Jawa Barat. Keberanian para pelaku usaha untuk memasarkan produknya lebih luas menjadi tantangan terbesar karen resiko maupun target penjualan yang belum memadai untuk wilayah di luar Desa Panenjoan. Pelaku usaha yang diwawancarai oleh peneliti merupakan para pelaku yang telah lama berjalan usahanya namun sampai saat ini masih memilih untuk menargetkan penjualannya di daerah Desa. Apabila dilihat dari sisi target pasar yang dituju saat ini saja dan melihat dari profil usaha yang telah berjalan cukup lama masih diperlukan beberapa pengelolaan manajemen usaha yang perlu ditingkatkan dengan menambah keberanian untuk mengambil resiko lebih dan sistem penjualan lainnya yang bisa membuat usaha tersebut dapat dicapai oleh seluruh masyarakat Indonesia.

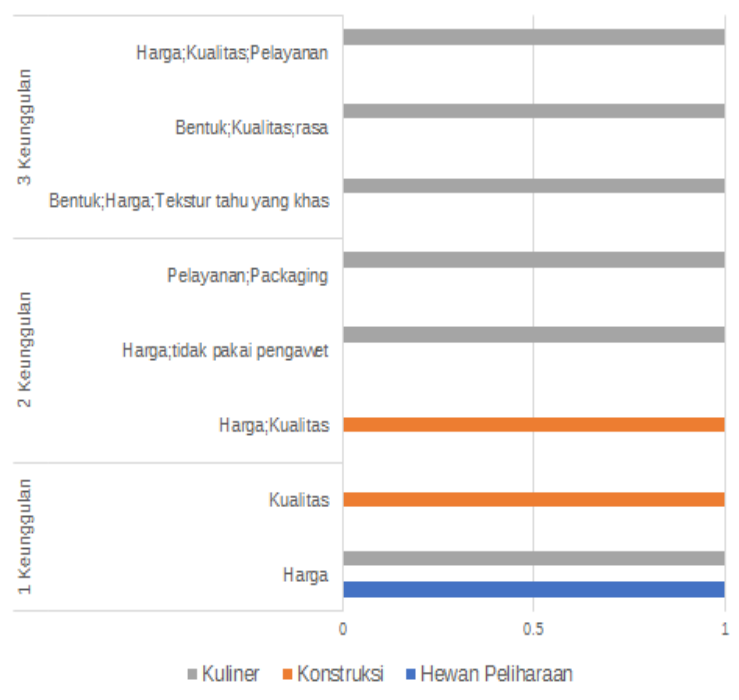

Sumber: Data diolah peneliti (2020)

Gambar 5. Bentuk Keunggulan dalam Persaingan UMKM Desa Panenjoan

Umumnya setiap usaha memiliki keunggulan yang berbeda. Peneliti mengklasifikasikan dalam beberapa hal untuk mengetahui keunggulan seperti apa yang ingin dicapai atau standar dari produk setiap usaha di Desa Panenjoan. Terdapat 3 klasifikasi yang terlihat, pelaku usaha berfokus pada 1 keunggulan, 2 keunggulan dan 3 keunggulan. Sebagian besar dari usaha kuliner memiliki beberapa keunggulan di dalam produknya. Hal ini terlihat dari masing-masing produk yang dibuat memiliki kualitas, rasa, dan harga yang berbeda. 3 aspek tersebut merupakan keunggulan yang seringkali disebutkan oleh pelaku usaha agar produknya dapat terus dikonsumsi oleh konsumen.

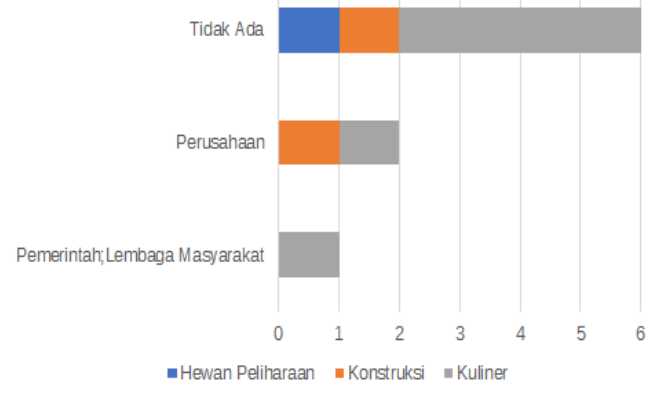

Sumber: Data diolah peneliti (2020)

Gambar 6. Dukungan Stakeholder UMKM Desa Panenjoan

Berdasarkan dari gambar 6, dapat diketahui bahwasebagianbesarpelakuusahatidakmendapatkan dukungan stakeholder Desa. Penyampaian informasi mengenai program yang ada ataupun informasi mengenai kebutuhan bagi pelaku usaha yang tidak cukup tertera sehingga minimnya program yang dilaksanakan di Desa. Adanya dukungan stakeholder 
terhadap pelaku usaha, tentu saja bisa meningkatkan pengemabangan usaha, misalkan dengan akses untuk mencapai target pasar yang lebih luas atau permodalan bagi pelaku usaha yang membutuhkan. Tidak hanya itu, tingkat persaingan bisa meningkat untuk mencapai keunggulan bersaing bagi setiap usaha yang berada di Desa.

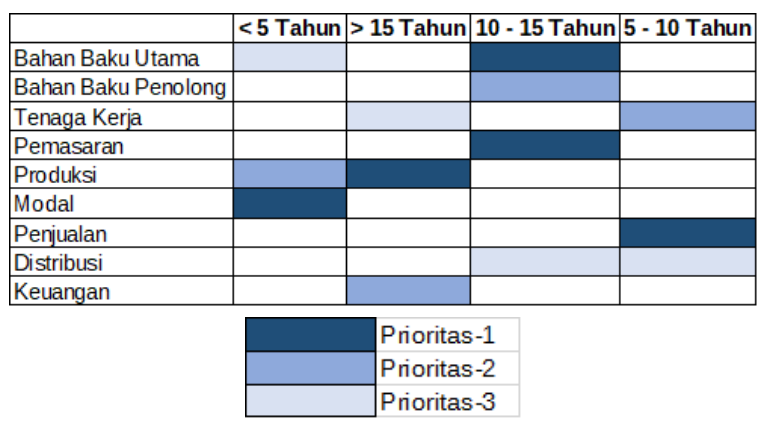

Sumber: Data diolah peneliti (2020)

Gambar 7.3 Prioritas Fokus Utama UMKM Desa Panenjoan

Terakhir dari data yang didapatkan, peneliti melihat bahwa diperlukannya tingkat perhatian bagi pelaku usaha di dalam usahanya sendiri. Secara keseluruhan, hal ini dilihat dari kelompok lamanya usaha tersebut bergerak dan 3 prioritas bagi pelaku usaha ketika melakukan usahanya. Terlihat di gambar 7 , bahwa bagi pelaku usaha yang telah berdiri kurang dari 5 tahun masih berfokus terhadap modal yang dimilikinya. Modal bisa jadi menjadi salah satu fokus utama ketika usaha tersebut baru berdiri karena untuk memperluas pasar maka diperlukan pula bahan baku yang lebih besar. Ketika daya produksi yang lebih besar maka akan ada tuntutan untuk memiliki mesin atau peralatan yang dapat mempermudah produksi produk yang lebih mudah. Selain itu, tingkat bahan baku utama akan menjadi perhatian lainnya ketika pelaku usaha perlu mempertahankan tingkat kualitas produk yang dimilikinya.

\section{SIMPULAN}

Secara keseluruhan usaha di Panenjoan memiliki potensi untuk dikembangkan, hanya memerlukan keterampilan tambahan untuk pengelolaan pengelolaan yang strategis. Banyaknya usaha kuliner, bisa menjadi salah satu pertimbangan desa untuk menjadikan usaha kuliner menjadi usaha unggulan desa. Rekomendasi yang dapat diberikan seperti Bantuan berupa kemudahan untuk mendapatkan bahan baku atau legalitas usaha bisa menjadi langkah untuk memulai pengembangan UMK dan membentuk Forum UMKM di Desa dan menguatkan jejaring dapat mengeratkan setiap pengusaha untuk berkolaborasi.

\section{DAFTAR PUSTAKA}

Ebert, J., \& Griffin, W. (2019). Business Essentials, 12th Edition. New York, NY: Pearson.

Mantra, I.B. (2004). Filsafat Penelitian dan Metode Penelitian Sosial. Yogyakarta: Pustaka Belajar.

Moeliono dan Djohani Rianingsih. (1996). Kebijakan dan Strategi Penerapan PRA dalam Pengembangan Program. Bandung: Driya Media.

Suci, Y. R. (2017). Perkembangan UMKM (Usaha mikro kecil dan menengah) di Indonesia. Cano Ekonomos, 6(1), 51-58.

Sugiyono. (2010). Metode Penelitian Administrasi. Bandung: Alfabeta 